\title{
THE IMPACT OF DISCOUNT FRAME AND TYPE OF PRODUCT ON PURCHASE INTENTION
}

\author{
Reliano Aldoreno \\ Program Studi Magister Manajemen Universitas Tarumanagara \\ aldorenoreliano@yahoo.com \\ Chairy \\ Program Studi Magister Manajemen Universitas Tarumanagara
}

Masuk : 06-05-2020, revisi : 24-06-2020 diterima untuk diterbitkan : 25-06-2020

\begin{abstract}
In this modern era, shifting the type of product from physical to digital has been popular. As an example, a textbook that been used by students in university may be acquired in the digital form which is an e-book. Marketing promotion is not only for a textbook, yet ebook should be treated the same. Online seller in Indonesia does promotion which is price discount to attract customer. Accordingly, there are two types of price discount frames which are $\%$ form or absolute form. Both may attract customers differently. Therefore this research aimed to find the impact of discount frame and type of product on customer purchase intention. The sample number is 92 students who take management Master's Degree at Tarumanagara University and the object of this research is purchase intention. This research used experimental design $2 \times 2$ factorial. SPSS program is used to do an ANOVA analysis. The first independent variable is the discount frame with two sub-factorials which are \% discount and Rp discount. The second independent variable is the type of product with two sub-factors which are textbooks and e-book. The result showed that type of product has a significant effect on customer purchase intention. There is no significant effect of the discount frame on purchase intention. The research result also showed that type of product does not moderate the relationship between discount frame and customer purchase intention.
\end{abstract}

Abstrak : Pada zaman modern saat ini, perkembang bentuk produk dari bentuk fisik menjadi digital semakin banyak. Sebagai contoh, textbook yang dapat diakses digital dan dikenal dengan istilah $e$-book. Promosi marketing tidak hanya berlaku untuk textbook, melainkan $e$ book juga. Penjual online di Indonesia melakukan promosi yaitu diskon harga untuk menarik perhatian konsumen. Terdapat dua jenis discount frame yaitu diskon $\%$ atau potongan harga dimana dapat menarik perhatian konsumen secara berbeda. Maka dari itu, penelitian ini bertujuan untuk mengetahui pengaruh discount frame dan type of product terhadap minat beli konsumen. Jumlah sampel adalah 92 siswa yang mengambil gelar Magister Manajemen di Universitas Tarumanagara dan objeknya adalah minat beli konsumen. Penelitian ini menggunakan desain faktorial $2 \times 2$. Program SPSS digunakan untuk melakukan analisis ANOVA. Variabel independen pertama adalah discount frame dengan dua sub-faktorial yaitu diskon \% dan diskon Rupiah. Variabel independen kedua adalah type of product dengan dua sub-faktor yaitu buku textbook dan $e$-book. Hasil analisa menunjukkan bahwa type of product memiliki efek yang siginifikan terhadap purchase intention. Tidak ada pengaruh yang signifikan antara discount frame dan purchase intention. Hasil analisa juga menunjukan bahwa type of product tidak memoderasi hubungan antara discount frame dan purchase intention

Keywords : Discount Frame, Type Of Product, Purchase Intention, Anova 


\section{INTRODUCTION}

Nowadays, students of a renowned university in Indonesia especially located in the heart of Indonesia has a learning system on campus developed well by using a textbook, e-book computer, projector, and other supported hardware systems. The teaching and learning process has been presented in front of the class using a projector while the lecturer elaborates on the learning materials. The textbook is a source that provides a material course for a formal study of a specific subject. Even though $e$-books provide material courses, they still cannot replace the textbook. There are several reasons, such as textbook grant visual attractiveness that produce visual stimuli and provide physical sensation from the pages (Abel, 2009). However, research by Khalid (2014) discovered that students in universities who don't acquire textbooks and $e$ books are even worse rather than those who do. The research found that the group of students that does not acquire books is larger in freshmen year.

The price discount itself is a reduction from the initial price to attract customers' intention (Yin \& Huang, 2014). Several discount messages can be applied to reduce initial price, percentage (\%) discount and nominal (Rp) discount. Both of them have the same amount of value but affect customers in different ways. This is called frame effect where the consumer is given information in two or more different ways with the same meaning, but cause different response (Biswas \& Grau, 2008).

To sum up, the design of this research is $2 \times 2$ factorial design with the subject of the research is students who take management Master's Degree at Tarumanagara University. The independent variables consist of a price discount frame with two factors which are discount frame (\%) and absolute frame (Rp) and type of product with two factors which are digital goods $(e-b o o k)$ and physical goods (textbook). As a result, it is predicted that a relation between price discount, either percentage or nominal reduction, and purchase intention is affected by the type of the product (e-book \& textbook).

The objectives of this research are to discover and verify the significance of the relationship between the discount frame on purchase intention and discover and verify the significance of the relationship between the type of product on purchase intention.

\section{LITERATURE REVIEW Price Discount}

Price discount has been defined as short-term deductions from prices listed when all buyers are equally acceptable for price reductions (Chen, Monroe, \& Lou, 1998). It is one of the marketing strategies by reducing the selling price that will cause to attract consumers to buy the product. Usually, the price discount is used when the product life cycle is high. It will boost the sales volume and will reduce the product life cycle (Guerreiro, Santos, Silveira, \& Ong, 2004). Customer who has been searching for the specific product and find a discount applied to the product will find treasurable and gives them extra joy from getting the item (Meuhlbacher, Kirchler, \& Kunz, 2011).

\section{Price Discount Frame}

The price discount frame has a meaning of delivering messages of a reduction in selling prices to consumers in several ways. It affects the decision of consumers by directive information given to evaluate a product (Kahneman \& Tversky, 1979). The price discount frame can be adjusted into percentage form or absolute price form (Bogomolova \& Dunn, 2012). When the discount is displayed in percentage or absolute frame, it will cause a different response (Heath, Chatterjee, \& France, 1995). The result of the difference between the two prices discount frame is the response of consumers according to the discount is greater felt in the percent off especially in the low priced product (Chen, Monroe, \& Lou, 1998). Also, the larger amount of the percent (33\% off) will impact the interest of consumers even if the value of the small percentage (5\% off) is the same (Kahneman \& Tversky, 1979). 


\section{E-book}

The $e$-book has been recently used in this millennia's era and the users are increasing. It consists of a picture, figure, chart, text, or both (Gardiner, Eileen, \& Ronald, 2010). Saleh and Mashhour (2015) have researched the main point is the readers can access $e$-book anywhere, even in a house, vacation, etc. Most people agree that an $e$-book advantage is being loved where it can be accessed anywhere.

\section{Purchase Intention}

Purchase intention defines as an individual's conscious plan to make an effort to purchase a brand (Rodriguez, 2008). When we are hungry, we think to eat something. Therefore, we have the intention to purchase food to fulfill our stomach. In addition, purchase intention represents the possibility that consumers will plan or be willing to purchase a certain product or service in the future (Wu, Yeh, \& Hsiao, 2011). Many variables influence the intention of the consumer while choosing the item and the final choice depends on the intention of the consumer with big internal variables (Kotler \& Keller, 2016).

\section{HYPOTHESIS}

The message frame is the same information delivered in different ways. It could affect the response of consumers in terms of purchase intention and decision behavior (Biswas \& Grau, 2008). A discount that shown in percentage will most likely increase the purchase intention of consumers on the low-price product (McKechnie, Devlin, Ennew, \& Smith, 2012). Although the value of the discount is the same, using an absolute discount will show a relatively small nominal. McKechnie, Devlin, Ennew, \& Smith (2012) indicated a significant relationship between discount frame with purchase intention on low price product such as chocolate. Moreover, an absolute discount leads to increase customer interest for the high-price product where it shows a high price value reduction (McKechnie, Devlin, Ennew, \& Smith, 2012).

\section{H1 : Discount frame affects purchase intention significantly}

A study from Liao (2016) regarding static e-book's purchase intention increase due to several benefits for readers. The static e-book is composed using PDF and able to display text, graph, and pictures. A tablet and a handphone will be able to read the file. Therefore, people can open the $e$-book in the workplace easily and that is what they need. Additionally, readers are more focused when reading $e$-books. That benefit increases the $e$-book's purchase intention. Research by Khalid (2014) indicates that students in Southern Polytechnic State University still preferred using a printed textbook. The main reasons for their choice are accessibility and userfriendliness in taking notes, easy to use where students usually do highlight while studying, and finding specific sections.

\section{H2 : Type of product affects purchase intention significantly}

When a consumer is confronted with a discounted item, but the discount is shown in different formats that will trigger the attention of the consumer. A study from McKechnie, Devlin, Ennew, \& Smith (2012) shows that the significance of the product's low price with a percentage discount on buying interest is higher than the absolute discount shown. In this study, the subject is the purchase intention of when buying a book. Today, together with technology development, the format of books has been developed into textbooks and e-books. Where textbook is a physical product and $e$-book is a digital product. Many studies determine that each form has its advantages and has an impact on purchase intention. It causes a relationship between discount frame (absolute or \%) to purchase intention on books is affected by the type of product (textbook or e-book).

H3 : The effect of the discount frame on the purchase intention is moderated by type of product 


\section{RESEARCH METHODOLOGY}

At first, a pilot study is conducted to gather information regarding the average selling price and establish the size discount. This pilot study is adopted from a study by Chairy (2005) where the independent variable is going to ask the respondents using a survey before the real studies. It becomes a starting procedure that needs to be set up and generally helps the planning of the main study (Arnold, Burns, Adhikari, E, Meade, \& Cook, 2009). Then, the real survey has a total respondent of 92 . The respondents were randomly assigned to one of four scenarios. For each scenario, the respondents have to measure consumer purchase intention. The scale from 1 to 7 where 1 is the lowest purchase intention and 7 is the highest purchase intention. This research has the goal to investigate the impact between discount frame and type of product on the purchase intention. This research consisted of two discount frame (\% and Rupiah) $\mathrm{x}$ two type of product (textbook and e-book). A factorial design is used due to several combinations of the independent variable (Bordens \& Abbott, 2018). Table 1 shows the data to be observed and between each variable has linked to cultivating a relationship that will be observed. Therefore, it brings out several scenarios that will be used to be a survey to the respondents.

Table 1.

Factorial Design $2 \times 2$

\begin{tabular}{|c|c|c|}
\hline & \multicolumn{2}{|c|}{ Discount frame } \\
\hline $\begin{array}{c}\text { Type of } \\
\text { Product }\end{array}$ & $\%$ & Rupiah \\
\hline Textbook & Scenario 1 & Scenario 2 \\
\hline E-book & Scenario 3 & Scenario 4 \\
\hline
\end{tabular}

After the data is collected, then normality testing and homogeneity testing is conducted. Thus, the ANOVA analysis can be operated.

\section{RESULTS AND DISCUSSIONS}

The Kolmogorov-Smirnov shows a significant value of $0.200>0.05$ which can be concluded that the data is processed into a parametric test due to assumptions of normality is satisfied. Then, the Levene statistic shows the significant value of Purchase intention in Based on the Mean row is $0.841>0.05$ where we can conclude that the data is homogeneity. After the data has been successfully checked and validated, the data is used in the ANOVA analysis.

Table 2

The first hypothesis is to verify that the discount frame affects purchase intention significantly. The survey used a discount of $10 \%$ or Rp. $40.000,00$ reduction. The discount number is obtained from the pilot study where the usual discount got when respondents purchase a book.

Test of Between-Subjects Effects Results

Based on the result in Table 2, the independent variable discount frame has a significant value $0.510>0.05$ which means that there is no significant effect between the discount frame on purchase intention. It can be concluded that the discount given is $10 \%$ or reduction Rp. 40.000,00 has not significantly affect customer's purchase intention to buy a book.

The second hypothesis is to verify that the type of product affects purchase intention significantly. The type of product is a variable that the customer considers when the customer wants to buy a book. The types of product in this research are textbook and e-book. 
Based on the result in table 2, the type of product has a significant value of $0.036<0.05$ which can be concluded that it has a significant influence on purchase intention. Therefore, the type of product is a variable that considers by the customer in the buying book process.

Table 2 shows that the significance value of interaction $\operatorname{sig}(0.826)>\alpha 0.005$ which can be concluded that the $\mathrm{H} 3$ is rejected. Variable discount frame have no interaction effect on the type of product that affects purchase intention. To sum up, the effect of the discount frame on purchase intention is not influenced by the type of product.

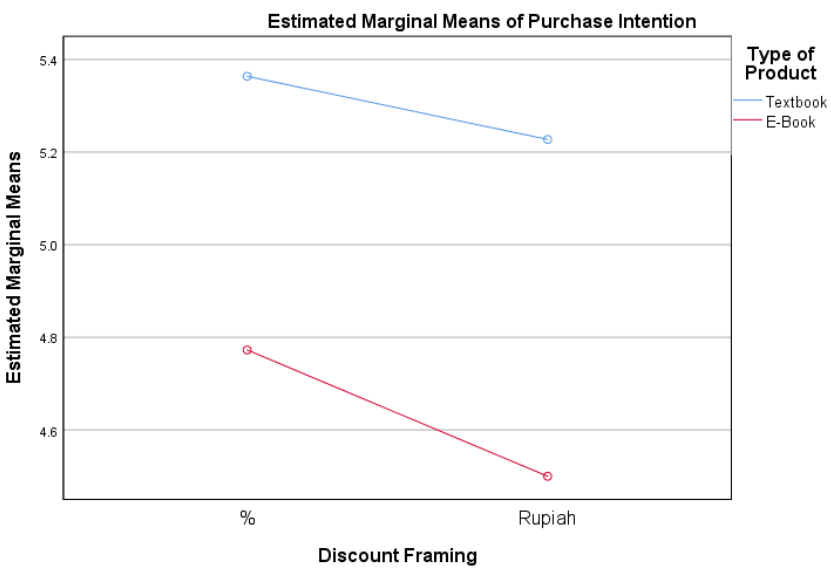

Figure 1

Interaction Effect between Discount Frame and Type of Product

Regarding the discount frame has not significantly affect customer purchase intention. However, Figure 1 shows that discount that displays in $\%$ has a higher value of purchase intention than display in Rupiah in terms of buying books. The price of a book that been asked in the survey is $\mathrm{Rp} 400.000,00$. The book can be considered as a low price product.

Also, the highest means is the combination of variable discount \% and textbook. It means from scale $1-7$, people have a level of purchase intention is 5.4 to buy a book. It can be considered it is a high purchase intention. On the other hand, an $e$-book that shown in Rupiah display is the lowest purchase intention.

\section{CONCLUSION AND RECOMMENDATION}

The result drawn from the analysis is that the type of product greatly influences the purchase intention. The discount frame, however, has no impact on the purchase intention. The relation between the discount frame on purchase intention does not affected by the type of product. The result may be used to other objects that have two types of form, which are digital and physical, e.g. photos, money, gold, etc.

Books are used as a source of study by many learning institutions, especially universities. The lecturers mostly present a lesson using a computer and projector, but the materials are still sourced from books. Therefore, books for students in universities are an essential need to study. Even though this research showed that the most of the students prefer using a textbook, but some students still chose $e$-book. In order to maintain students to have books, universities can develop a price promotion by a partnership with bookstores E.g., if students purchase books, they will get a special discount for being a member of the particular university. This will increase students' motivation to read, develop a habit to get information from trusted sources, and also save money.

In this millennial era, digital products show rapid development in online media, such as business and finance. In this era, markets are even digital. People maintain transactions through their gadgets. People are not keeping their money in banks or wallets anymore, instead, electronic wallets, or usually called e-wallet, are the trend. Therefore, digital products may be more popular in the future.

As a marketer, the price promotion of price discount may impact the purchase intention. Based on the previous studies and this research, the low-price product will be more attractive when the price discount is displayed in \%. This also applied in an online transaction where the message frame will be more attractive due to the digital design. In addition, consumers also recognize the discount easier with \% discount. 
Bookstores may be reduced in offline consumer traffic due to online shopping that triggers online traffic. The advantage of online purchasing is consumers do not have to come searching for the products they want to several bookstores anymore, instead, they can just tap their gadgets and find the products. If they intend to acquire them, then they can come to the store or just purchase the e-book. In this research, the price of the book is Rp400.000,00. Therefore, another study may occur for the digital type of this product at a higher price. E.g., an $e$-book that costs greater than Rp1.000.000,00.

\section{REFERENCE}

Abel, D. (2009). Welcome to the Library. Say Goodbye to the Books. The Boston Globe.

Biswas, D., \& Grau, S. (2008). Consumer Choices Under Product Option Framing : Loss Aversion Principles or Sensitivity to Price Differentials? In Psychology and Marketing, 399-415.

Bogomolova, S., \& Dunn, S. (2012). Price Framing Techniques in Supermarkets Around the World. Paper presented at the EMAC, Lisbon.

Bordens, S. K., \& Abbott, B. B. (2018). Research Design and Methods : A Process Approach. USA : McGraw-Hill.

Chairy. (2005). Studi Pengambilan Keputusan Konsumen oleh Forward Looking Consumer : Penerapan Model Analisis Varians Multivariat Non-Hirarki. Jurnal Manajemen Indonesia , 2 (1), 1-11

Chen, S., Monroe, K., \& Lou, Y. (1998). The Effects of Framing Price Promotion Messages on Consumers' Perception and Purchase Intentions. Journal of Retailing, 73 (3), 353-72.

Gardiner, Eileen, \& Ronald, G. M. (2010). The Electronic Book. In Suarez, M. Felix, \& H. R. Woudhuysen, The Oxford Companion to the Book (p. 164). Oxford: Oxford University Press.

Guerreiro, R., Santos, A., Silveira, G. J., \& Ong, B. (2004). Cost Implications of Bonus Pack Promotions Versus Price Discounts. American Business Review, 72-81.

Heath, T., Chatterjee, S., \& France, K. (1995). Mental Accounting and Change in Price: The Frame Dependence of Preference Dependence. Journal of Consumer Research, 90-7.

Kahneman, D., \& Tversky, A. (1979). Prospect Theory: An Analysis of Decision Under Risk. In Econometrica (pp. 263-91).

Khalid, A. (2014). Text Books : Ebook Vs. Print. Journal of Education and Human Development, 243-258.

Kotler, P., \& Keller, K. L. (2016). Marketing Management. England : Pearson.

Liao, H. (2016). The Effect of Presentation Types and Flow on E-book Purchase Intention. Eurasia Journal of Mathematics, Science \& Technology Education, 669 - 686.

McKechnie, S., Devlin, J., Ennew, C., \& Smith, A. (2012). Effects of Discount Framing in Comparative Price Advertising. European Journal of Marketing, 4 (11/12), 1501-1522.

Meuhlbacher, S., Kirchler, E., \& Kunz, A. (2011). The Impact of Transaction Utility on Consumer Decisions : The Role of Loss Aversion and Acquistition Utility. Journal of Psychology, 217-223.

Rodriguez, K. P. (2008). Apparel Brand Endorsers and Their Effects on Purchase Intention: A Study of Philippine Consumers. In Philippine Management Review, 83-99.

Saleh, Z. I., \& Mashhour, A. S. (2015). The Impact of E-books on The Printed Books : E-books Popularity, Growth and Future. Fifth International on e-Learning (ECONF 2015).

Wu, P. C., Yeh, G. C., \& Hsiao, C. (2011). The Effect of Store Image and Service Quality on Brand Image and Purchase Intention for Private Label Brands. Australasian Marketing Journal , 19, 30-39.

Yin, X., \& Huang, J. (2014). Effects of Price Discounts and Bonus Packs on Online Impulse Buying. Social Behavior \& Personality : An International Journal, 42 (8), 1293-1302. 